\title{
Does Electricity Consumption affect Economic Growth in Bangladesh?
}

\author{
Sk. Sharafat Hossen" and Md. Mahbubul Hasan \\ Economics Discipline, Khulna University, Khulna-9208, Bangladesh \\ "Corresponding author: sharafatku@gmail.com
}

\begin{abstract}
This research attempts to uncover the relationship between electricity consumption and economic growth in Bangladesh adopting co-integration and causality analysis using time series data spanning from 1972 to 2011. It takes under consideration the variables Gross Domestic Product (GDP), Electricity Consumption (EC) and Carbon dioxide emission $\left(\mathrm{CO}_{2}\right)$ to fulfill the research objective. Adopting Augmented Dickey Fuller (ADF) and Phillips-Perron (PP) tests of unit root, it is observed that the first differences of all the three variables are stationary which indicates that the variables are co-integrated of order 1 . The trace test and maximum Eigen value of Johansen co-integration test confirm that all the variables are cointegrated with one co-integrating vector. Besides, using Impulse Response Functions (IFRs) of Vector Auto-regression (VAR), the possible forecasting for the relationship of the variables has been performed. The empirical result based on Granger F-test reveals existence of unidirectional causality running from Electricity Consumption (EC) to Gross Domestic Product (GDP), Electricity Consumption (EC) to Carbon dioxide emission $\left(\mathrm{CO}_{2}\right)$ and Gross Domestic Product (GDP) to Carbon dioxide emission $\left(\mathrm{CO}_{2}\right)$ without having any reverse causation. Thus, it implies that Electricity Consumption (EC) affects both Gross Domestic Product (GDP) and Carbon dioxide emission $\left(\mathrm{CO}_{2}\right)$ and Gross Domestic Product (GDP) drives only Carbon dioxide emission $\left(\mathrm{CO}_{2}\right)$ in short run without feedback in the long run.
\end{abstract}

Keywords: Electricity Consumption, Economic Growth, Co-integration, Impulse Response Function and Causality

Electricity is considered as the essential infrastructural input for economic growth and development of an economy due to its widespread use in households and industries. That is why the consumption demand for electricity is increasing over the years in both households and industries. This far-reaching demand for electricity is created by some factors of economic growth and development such as rising standard of living, population growth, rapid industrialization, extensive urbanization and modernization of agricultural sector and so on. Ferguson et al. (2000) found that there is a strong correlation between electricity consumption and economic growth in a cross-country time series analysis based on more than one hundred countries without having any direction of causality. A few studies established unidirectional causality from economic growth to energy consumption (Glasure and Lee, 1998; Narayan and Smyth, 2009). Yang (2000), Narayan and Singh (2007), and Squalli (2007) found the direction of causality running from energy consumption to economic growth. On the other hand, no causality between economic growth and energy consumption was found by $\mathrm{Yu}$ and Choi (1985), Stern (1993), and Cheng (1999), and Imran (2010).

In case of South Asian countries, a study conducted by Ghosh (2002) revealed that unidirectional causality existed running from economic growth to electricity consumption using annual time series data covering the period from 1950-51 to 1996-97 in India. He again conducted the same research in 2009 and found the same result that there is unidirectional causality running from economic growth to 
electricity consumption in the short-run. Another study conducted by Lean and Shahbaz (2012) found that electricity consumption has positive impact on economic growth and bidirectional causality has been identified between electricity consumption and economic growth in Pakistan. However, Ahmad and Jamil (2010) found the presence of unidirectional causality from economic growth to electricity consumption. Besides, not only current but also past changes in electricity supply have a major influence on a change in real GDP has been pointed out by Morimoto and Hope (2004) in Sri Lanka. Moreover, Saeki and Hossain (2011) pointed out prevalence of unidirectional causality running from economic growth to electricity consumption in India, Nepal and Pakistan, and from electricity consumption to economic growth in Bangladesh.

If we look at the case of Bangladesh, a positive relationship between energy consumption and economic growth is found (Asaduzzaman and Billah, 2006). The results of Buysse et al. (2012) shows that unidirectional causality exists from energy consumption to economic growth both in short and long run, while bidirectional long-run causality exists between electricity consumption and economic growth but no causal relationship prevails in short-run. Besides, Alam and Sarker (2010) has applied Granger causality tests to check the relationship between economic growth and electricity generation and found that there exists short-run causal relationship running from electricity generation to economic growth without feedback. On the contrary, Mozumder and Marathe (2007) got quite opposite relationship that is unidirectional causality from GDP to electricity consumption for Bangladesh for the period 1971 to 1999 by employing co-integration and vector error correction model (VECM).

The empirical outcomes on different developing countries are very equivocal and even differ for the same country and are not conclusive. This is also true for Bangladesh. Therefore, to identify the relationship between electricity consumption and economic growth, to uncover the direction of causality to obtain transparent realization of the issues considered and to determine the policy strategies is essential. For this reason, the main purpose of this study is to uncover the causal relationship between electricity consumption and economic growth in Bangladesh considering time series data ranging from 1972 to 2011.

\section{Objective of the Study}

The objective of this study is:

(i) To uncover the causal relationship (short-run/ long-run) between electricity consumption (EC) and economic growth (GDP) in Bangladesh

\section{Data and Methods}

The empirical analysis of the study is conducted by using time series data with annual frequency spanning from 1972-2011 of electricity consumption (EC), gross domestic product (GDP), $\mathrm{CO}_{2}$ emissions from electricity and heat production $\left(\mathrm{CO}_{2}\right)$. These variables have been chosen by acquiring knowledge from the similar previous studies of different researchers and on the basis of the availability of reliable data. The choice of starting period is selected on the basis of the period of independence of Bangladesh and the ending period of the data series has been constrained by the availability of data from secondary sources. Table 1 shows the description of selected variable.

Table 1: Description of the Selected Variables

\begin{tabular}{|c|c|c|c|}
\hline Variables & $\begin{array}{c}\text { Unit of } \\
\text { measurement }\end{array}$ & $\begin{array}{c}\text { Duration } \\
\text { of data }\end{array}$ & $\begin{array}{l}\text { Sources } \\
\text { of data }\end{array}$ \\
\hline $\begin{array}{c}\text { Electricity } \\
\text { Consumption (EC) }\end{array}$ & $\begin{array}{l}\text { KWh (Kilowatt } \\
\text { hour per } \\
\text { capita) }\end{array}$ & 1972-2011 & WDI \\
\hline Real GDP (GDP) & $\begin{array}{c}\text { US\$ (at market } \\
\text { price in current } \\
\text { US\$) }\end{array}$ & 1972-2011 & WB \\
\hline $\begin{array}{c}\mathrm{CO}_{2} \text { Emissions from } \\
\text { Electricity and Heat } \\
\text { Production }\left(\mathrm{CO}_{2}\right)\end{array}$ & $\begin{array}{l}\text { Percentage (\% } \\
\text { of total fuel } \\
\text { combustion) }\end{array}$ & $1972-2011$ & WB \\
\hline
\end{tabular}

The data are analyzed to uncover the nexus among electricity consumption, real GDP (proxy of economic growth), $\mathrm{CO}_{2}$ emissions from electricity and heat production $\left(\mathrm{CO}_{2}\right)$. For this purpose, both descriptive statistics and advanced econometric model for time series analysis have been used. The following econometric tests have been conducted to properly address the objective of this study. 


\section{Unit Root Test}

Generally we see that time series data is nonstationary but the model can only be run once the given time series are stationary. According to the Engle and Granger (1987), if independent series are stationary then the series are said to be cointegrated. To investigate whether the given time series are stationary, there are several procedures (tests) in the econometric literature and each test has its own merits and demerits. In our study, we use Augmented Dickey Fuller (1981) and Phillips-Perron (1988) test to avoid the criticisms of individual test. Appropriate lag lengths are selected following Schwarz Information Criterion (SIC) method.

We performed the Augmented Dickey Fuller (ADF) tests based on the following model:

$$
\Delta y_{t}=\alpha_{0}+\alpha_{1} y_{t-1}+\sum_{t=1}^{n} \alpha_{2} \Delta y_{i}+e_{t}
$$

Where $\Delta=$ first difference operator, $\mathrm{n}$ = optimal number lags, $e_{t}=$ disturbance term considered as a white noise error, $\mathrm{y}=$ time series that is electricity consumption (EC), GDP and $\mathrm{CO}_{2}$ emission.

The Phillips-Perron (PP) test is based on the following model:

$$
\Delta Y_{t}=\alpha+\beta Y_{t-1}+\varepsilon_{t}
$$

Where $\Delta=$ first difference operator, $\alpha=$ constant, $\beta$ $=$ coefficient, $\varepsilon_{\mathrm{t}}=$ error term and $\mathrm{y}=$ time series that is electricity consumption, GDP and $\mathrm{CO}_{2}$ emission.

\section{Johansen Co-integration and VAR}

For co-integration test, it is required that the chosen time series i.e., electricity consumption (EC), GDP and $\mathrm{CO}_{2}$ emission to be integrated of the first order I (1), when this condition satisfy then one can move into examine the existence of long run cointegration relationship of the chosen time series. In this regards, Johansen co-integration test has been employed.

Johansen co-integration test indicates the maximum likelihood procedure for the identification of the existence of co-integrating vectors for chosen non-stationary time series data. The Johansen methods allow us to determining the number of co-integrating vector. Two different likelihood ratio test proposed by the Johansen are:

$$
\text { Trace Test }=\lambda_{\text {trace }}=-T \sum_{J=r+1}^{K} \ln \left(1-\hat{\lambda}_{J}\right)
$$

Maximum Eigen Value Test $=$

$$
\lambda_{\max }=-T \ln \left(1-\widehat{\lambda_{r+1}}\right)
$$

Where, $\mathrm{T}=$ Sample size and $\hat{\lambda}_{J}=$ Estimated values of characteristic roots ranked from largest to smallest.

It should be mentioned that trace test $\left(\lambda_{\text {trace }}\right)$ according to equation (iii) tests the null hypothesis of cointegrating vector against the alternative hypothesis of $\mathrm{n}$ co-integrating vectors and maximum Eigen value test $\left(\lambda_{\max }\right)$ according to equation (iv) tests the null hypothesis of $r$ co-integrating vectors against the alternative hypothesis of $r+1$ co-integrating vectors.

If two or more series are not co-integrated, Vector Auto-regression (VAR) is employed to investigate the integration in Vector Auto-regression (VAR) model. Appropriate lag lengths are selected according to the Schwarz Information Criterion (SIC) method. Equation (v) expresses VAR of order $p$ in the following way:

$$
z_{t}=c+A_{1} z_{t-1}+\ldots \ldots+A_{p} z_{t-p}+\mu_{t}
$$

Where, $z_{t}$ represents $n \times 1$ vector that integrated I (1) and $\mu_{t}$ is $\mathrm{n} \times 1$ vector innovations.

Thus, Pair-wise Granger causality can be captured based on Vector Auto-regression (VAR) model which is employed to determine the causality direction between electricity consumption, economic growth and $\mathrm{CO}_{2}$ emissions from electricity and heat production.

\section{RESULTS AND DISCUSSION}

\section{Trend of Electricity Consumption (EC)}

The electricity consumption in Bangladesh has increased significantly over the last three decades as the electricity used in every sphere of national economy. It is observed that (from the Fig. 1) the rate of growth of electricity consumption is approximately unchanged in 1980s. The reason behind this result is that it was the post liberation war period of Bangladesh. At that time Bangladesh was in the stage of industrial setup. That is why 
the growth rate of electricity consumption did not fluctuate significantly in this decade. In the very next decade, the growth rate was starting to rise slowly because the industrial setup was going to its operation stage.

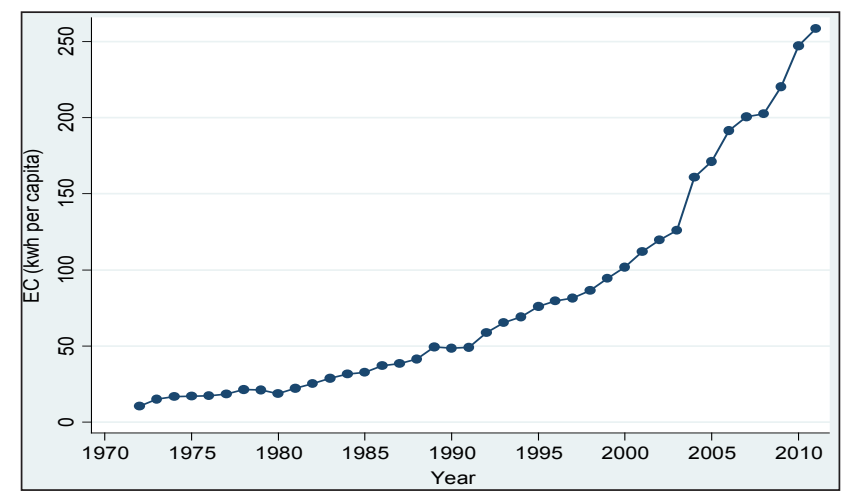

Fig. 1: Trend of EC in Bangladesh during 1972-2011

Source: Authors' compilation based on WDI, 2016.

The following ten years from 1991 to 2000 reveals that electricity consumption is rising quickly following rapid industrial development. The contribution of industry to GDP was rising to 21.7 percent in 1991 and to 25.9 percent in 2001 (Abdin, 2012). Besides, from this stage people of Bangladesh began to use hi-tech products like color television, refrigerator and computer which consume electricity at a great amount and industrial consumption of electricity was also increasing to the same extent. According to BPDB (2011), per capita electricity consumption increased from 75.88 kilowatt hour (KWh) in 1995 to $180.08 \mathrm{KWh}$ in 2011. Thus, the consumption of electricity was starting to increase rapidly.

\section{Trend of Gross Domestic Product (GDP)}

Gross Domestic Product (GDP) is one of the major macroeconomic indicators which indicates the state of economics development of a country. Fig. 2 represents the trend of GDP in Bangladesh for the selected time period. The trend of GDP of Bangladesh experienced slower rate of growth in 1980s. This is because it was after the liberation period of Bangladesh. That is why the growth rate of GDP was experiencing a very slower rate of growth. In this backdrop of deep macroeconomic crisis of late 1980s, a series of stabilization measures were undertaken in the economy of Bangladesh. As a result, the growth trend of GDP and macroeconomic stability were restored in the early 1990s. Bangladesh economy witnessed one percent higher economic growth rate (4.8 percent) in 1990s than that of (3.8 percent) the preceding decade of 1980s according to Bhattacharya (2002).

As a result of successful stabilization policy, the economy of Bangladesh was characterized by a record-low rate of inflation, an unprecedented build-up of external reserves and an improved domestic resource mobilization until the mid 1990s. But, after that period, there emerged inflationary pressure, decline in foreign reserve and government budgetary balance (Mahmud, 1997).

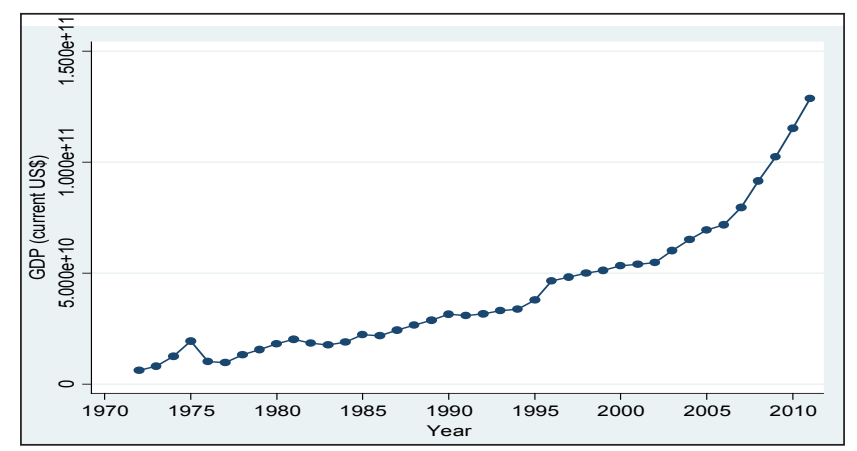

Fig. 2: Trend of GDP in Bangladesh during 1972-2011

Source: Author's compilation based on WB, 2016.

The trend of GDP of Bangladesh increased gradually after the 1990s but it became slower from 1995 to 2002 for political turmoil and natural disaster. Afterward, the growth rate was starting to increase drastically even during the global financial crisis of 2008 and had perhaps no significant negative impact on the GDP growth rate of Bangladesh.

\section{Trend of $\mathrm{CO}_{2}$ Emissions $\left(\mathrm{CO}_{2}\right)$}

Emission of carbon dioxide $\left(\mathrm{CO}_{2}\right)$ is often considered as an indicator of industrial development of a country and industrial sector is major source of electricity consumption all over the world and the same is also true for Bangladesh. Fig. 3 represents the trend of $\mathrm{CO}_{2}$ emissions in Bangladesh for the selected the period 1972-2011. In 1980s, the growth rate of $\mathrm{CO}_{2}$ emissions was relatively slower because it was the post liberation war decade for Bangladesh and there were a few industries which emit $\mathrm{CO}_{2}$. The growth rate of $\mathrm{CO}_{2}$ emissions was gradually increasing during the 1985 to 2005 with some fluctuations because of increasing industrial development.

Alam (2014) claims that $\mathrm{CO}_{2}$ emissions increase when contribution of industry and service to GDP 
is expansively rising. Manufacturing and industrial processes emit $\mathrm{CO}_{2}$ directly through fossil fuel combustion as well services indirectly through the use of electricity that is generated using fossil fuels.

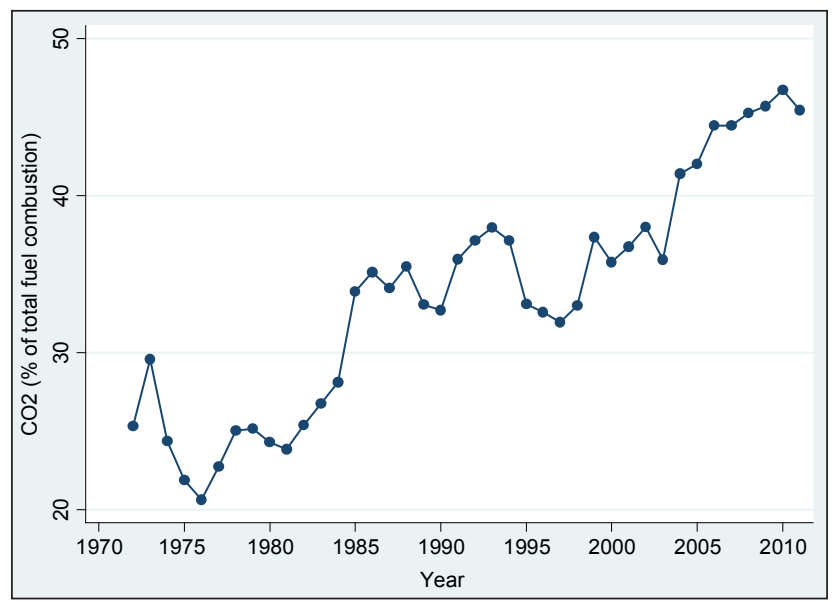

Fig. 3: Trend of $\mathrm{CO}_{2}$ Emissions in Bangladesh during 1972-2011

Source: Author's compilation based on WB, 2016.

All combine to produce large amounts of each type of greenhouse gas but specifically large amounts of $\mathrm{CO}_{2}$. After 1995, the growth rate was increasing drastically but it was again curbed for a few years for the measures taken to reduce the environmental hazard by taking necessary steps under United Nations Framework Convention on Climate Change. Just after a few years from 2005, the emission of $\mathrm{CO}_{2}$ was increasing at a great haste through fluctuation because of setting up coal based power plants.

\section{Relationship among EC, GDP and $\mathrm{CO}_{2}$ Emissions}

Among the selected variables (EC, GDP and $\mathrm{CO}_{2}$ emission) for conducting the research, it is found form the correlation matrix that there is strong positive correlation between electricity consumption (EC) and GDP which is confirmed by the Pearson correlation coefficient of 0.98 which is significant at 1 percent level of significance.

The variables electricity consumption (EC) and carbon dioxide emission $\left(\mathrm{CO}_{2}\right)$ are also very much positively correlated with each other where the correlation coefficient is 0.89 and which is significant at 1 percent level. Besides, the correlation coefficient between GDP and carbon dioxide emission $\left(\mathrm{CO}_{2}\right)$ is estimated 0.87 at 1 percent level of significance.
Thus, the selected variables are strongly correlated.

Table 2: Correlation Matrix of Electricity Consumption (EC), GDP and Carbon dioxide Emissions $\left(\mathrm{CO}_{2}\right)$

\begin{tabular}{ccccc}
\hline & Variables & EC & GDP & $\mathrm{CO}_{2}$ \\
\hline EC & $\begin{array}{c}\text { Pearson } \\
\text { Correlation } \\
\end{array}$ & 1.00 & $0.98^{* * *}$ & $0.89^{* * *}$ \\
GDP & $\begin{array}{c}\text { Sig. (2-tailed) } \\
\text { Pearson } \\
\text { Correlation }\end{array}$ & $0.98^{* * *}$ & 1.00 & $0.87^{* * *}$ \\
& $\begin{array}{c}\text { Sig. (2-tailed) } \\
\text { CO }\end{array}$ & 0.00 & $\cdot$ & 0.00 \\
$\mathrm{CO}_{2}$ & $\begin{array}{c}\text { Pearson } \\
\text { Correlation }\end{array}$ & $0.89^{* * *}$ & $0.87^{* * *}$ & 1.00 \\
& $\begin{array}{c}\text { Sig. (2-tailed) } \\
\text { Number of Observations }\end{array}$ & 0.00 & 0.00 & $\cdot$ \\
\hline
\end{tabular}

Source: Author's calculation based on WB and WDI, 2016.

\section{Result of Unit Root Test}

The outcome of ADF and PP unit root tests on both the level $(\mathrm{lag}=0)$ and first difference (lag=1) series of the variables GDP, $\mathrm{EC}$ and $\mathrm{CO}_{2}$ are placed in the Table 5.1 with necessary interpretation.

\section{Augmented Dickey Fuller (ADF) and Phillips- Perron (PP) Test}

Both ADF and PP test for level series of the selected variables claim that the null hypothesis of the presence of unit root in the selected variables should not be rejected. The reason behind this is not only ADF but also PP test statistic for each variable is greater than the critical values for level series in Table 3. Besides, MacKinnon (1996) one-sided $p$-values are insignificant for each variable in level series. Thus, the selected variables are not stationary. So, there is unit root in the time series in this regard. The result of the first difference of ADF and PP test has been represented in Table 3 where it is obvious that ADF and PP test statistic for each variable falls within the rejection region and $\mathrm{EC}$ and $\mathrm{CO}_{2}$ emission are stationary at 1 percent level and GDP is stationary at 10 percent level.

So, it can be decided that the null hypothesis of the presence of unit root is rejected for the variables and the selected variables are first-ordered integrated i.e. I (1) and subject to co-integration test from the perspective of not only ADF test but also PP test. 
Table 3: ADF and PP Test of Unit Root

\begin{tabular}{cccccc}
\hline & Variables & EC & GDP & $\mathrm{CO}_{2}$ & State of Stationary \\
\hline ADF & Level series & $5.10(-3.61)$ & $5.43(-3.61)$ & $-0.63(-3.61)$ & Non-stationary \\
Test & First difference & $-3.98^{* * *}(-3.62)$ & $-2.73^{*}(-2.61)$ & $-6.28^{* * *}(-3.62)$ & Stationary \\
PP & Level series & $7.81(-3.61)$ & $5.39(-3.61)$ & $-0.59(-3.61)$ & Non-stationary \\
Test & First difference & $-4.04^{* * *}(-3.62)$ & $-2.57^{\mathrm{a}}(-2.61)$ & $-6.28^{* * *}(-3.62)$ & Stationary \\
\hline
\end{tabular}

Note: ${ }^{* *} p<0.01,{ }^{*} p<0.1$ and $\left(^{a}\right)$ is considered rejection of null hypothesis at nearly 10 percent level in line with the ADF test since the corresponding $p$-value is 0.1088 . 't-statistics' or critical values are given in parenthesis and ADF test statistics are given without parenthesis.

Source: Author's calculation based on WB and WDI, 2016.

Table 4: Trace Statistics and Maximum Eigen Value

\begin{tabular}{cccccc}
\hline \multirow{2}{*}{ Null Hypothesis } & Alternative & \multicolumn{4}{c}{ Unrestricted Co-integration Rank Test } \\
\cline { 3 - 6 } & Hypothesis & Trace () & $\mathbf{9 5 \%}$ critical value & Max-Eigen () & $\mathbf{9 5 \%}$ critical value \\
\hline $\mathrm{r}=0$ & $\mathrm{r}=1$ & $31.91^{* *}$ & 29.80 & $22.40^{* *}$ & 21.13 \\
$\mathrm{r} \leq 1$ & $\mathrm{r}=2$ & 9.51 & 15.49 & 6.27 & 14.26 \\
$\mathrm{r} \leq 2$ & $\mathrm{r}=3$ & 3.24 & 3.84 & 3.24 & 3.84 \\
\hline
\end{tabular}

Note: ${ }^{* *} p<0.05$; ' $\mathbf{r}$ ' is the co-integration vector. Max-Eigen represents maximum Eigen value.

Source: Author's calculation based on WB and WDI, 2016.

\section{Result of Co-integration Test}

Though a time series is independently non stationary, a linear combination between two or more time series can be stationary is referred to as co-integration. Co-integration of two (or more) time series implies that there is a long run or equilibrium relationship between them otherwise short run relationship is considered. As it is found that the variables under consideration are integrated of order 1, the co-integration test is required to execute.

\section{Order of Co-integration (Result of Johansen test)}

The researcher applies Johansen Co-integration test for identifying the order of co-integration. The result of trace statistics and maximum Eigen value has been represented in Table 4 in this regard. The practice of 90 percent confidence interval expands the interval of confidence and hence raises the probability of accepting null hypothesis. For this reason, Enders (1995) advocates to use 95 percent and 99 percent confidence interval to test the hypothesis. Accordingly, the researcher uses 95 percent confidence interval.

\section{Trace Statistics and Maximum Eigen Value}

In the first case, the result of trace statistics and maximum Eigen value illustrates that it is likely to reject the null hypothesis of no co-integrating vector $(r=0)$ and accept the alternative hypothesis of one co-integrating vector in the three variables as the value of trace statistics 31.91 surpasses the 95 percent critical value of the statistics which is 29.80 and the value 22.40 exceeds the 95 percent critical value of the value which is 21.13 in Table 4 . In the second case, researcher tests the null hypothesis of maximum one co-integrating vector $(r \leq 1)$ against the alternative hypothesis of two co-integrating vectors $(r=2)$. As the trace statistic and maximum Eigen value are less than the critical value at 95 percent confidence interval, it is not possible to reject the null hypothesis.

In the same way, when the null hypothesis is $\mathrm{r} \leq$ 2 against the alternative hypothesis $r=3$, it is also not possible to reject the null hypothesis because the trace statistic and maximum Eigen value are less than the 95 percent critical value. Thus, the acceptance of null hypothesis of $\mathrm{r} \leq 1$ and $\mathrm{r} \leq 2$ confirms no more than one co-integrating vector at the 95 percent confidence interval.

In fine, it can be said from the trace test and maximum Eigen value test that there is one cointegrating vector in the time series of EC, GDP and $\mathrm{CO}_{2}$. So, there is no long run relationship among them. Therefore, VAR and short run Granger causality are employed. 


\section{Result of Impulse Response Function (IRF) of Vector Auto-regression (VAR)}

Impulse response functions illustrate the response of endogenous macroeconomic variables at the time of the shock and over subsequent points in time. According to Lutkepohl (2008), Impulse response functions are used to illustrate how the economy responses over time to exogenous impulses which are called shocks by economists and are often represented in the perspective of a VAR analysis.

\section{Response of Electricity Consumption (EC) to GDP}

The left graph of the first row of Fig. 4 represents the response of endogenous variable EC which is represented by red colored dotted curves to the exogenous shock of GDP which is represented by blue colored solid curve over time. Here, it is obvious that GDP growth can cause EC either positively or negatively. It implies that with the increase in GDP growth in the upcoming period, EC may either increase or decrease.

\section{Response of GDP to Electricity Consumption (EC)}

In the middle row of Fig. 4, the left graph represents the response of GDP which is represented by red colored dotted curves to EC which is represented by blue colored solid curve for the upcoming period. The response of GDP to the increase in EC may be positive for the upcoming years for both the positive and the negative part of the graph.

\section{Response of GDP to Carbon dioxide Emission $\left(\mathrm{CO}_{2}\right)$}

It is evident from the right graph of middle row of Fig. 4 that response of GDP which is represented by red colored dotted curves to $\mathrm{CO}_{2}$ emission which

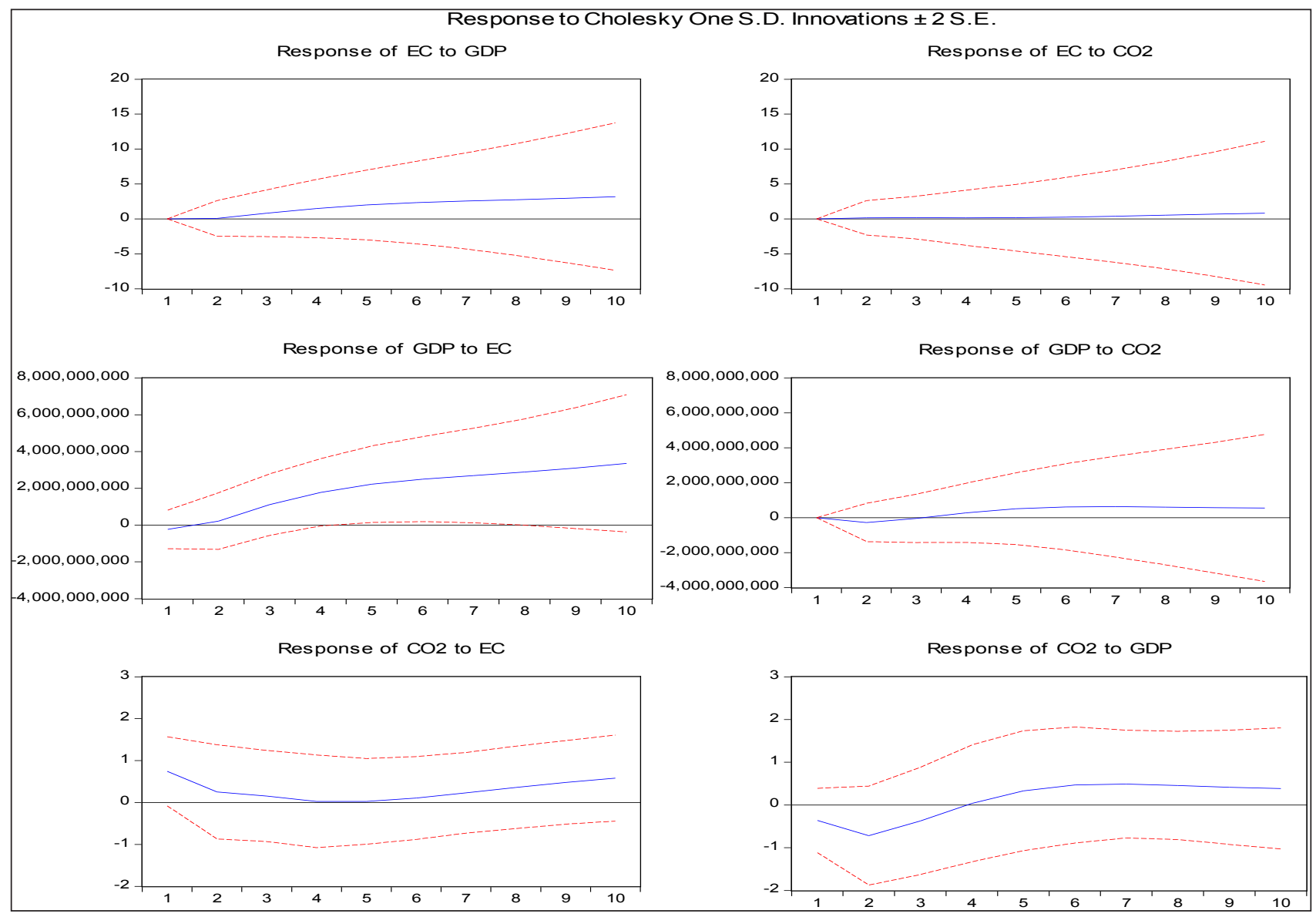

Fig. 4: Impulse Response Functions

Note: GDP is expressed in current US\$. EC is expressed in kwh per capita. $\mathrm{CO}_{2}$ is expressed in percentage of total fuel combustion. Red colored curves represent response functions and blue colored curves represent independent function.

Source: Author's calculation based on WB and WDI, 2016. 
Table 5: Pair-wise Granger Causality Tests

\begin{tabular}{clcc}
\hline Null Hypothesis & Alternative Hypothesis & F-statistics & Result \\
\hline GDP does not Granger Cause EC & GDP Granger Cause EC & 1.13 & \\
EC does not Granger Cause GDP & EC Granger Cause GDP & $4.12^{* *}$ & EC $\rightarrow$ GDP \\
$\mathrm{CO}_{2}$ does not Granger Cause EC & $\mathrm{CO}_{2}$ Granger Cause EC & 0.71 & \\
EC does not Granger Cause CO & EC Granger Cause $\mathrm{CO}_{2}$ & $7.76^{* * *}$ & $\mathrm{EC} \rightarrow \mathrm{CO}_{2}$ \\
$\mathrm{CO}_{2}$ does not Granger Cause GDP & $\mathrm{CO}_{2}$ Granger Cause GDP & 0.79 & \\
GDP does not Granger Cause $\mathrm{CO}_{2}$ & GDP Granger Cause $\mathrm{CO}_{2}$ & $2.26^{*}$ & GDP $\rightarrow \mathrm{CO}_{2}$ \\
\hline
\end{tabular}

Note: ${ }^{* * *} p<0.01,{ }^{* *} p<0.05,{ }^{*} p<0.1$.

Source: Author's calculation based on WB and WDI, 2016.

is represented by blue colored solid curve may be either positive or negative. But, it is not possible to ascertain whether the response will be positive or negative.

\section{Response of $\mathrm{CO}_{2}$ Emission $\left(\mathrm{CO}_{2}\right)$ to Electricity Consumption (EC)}

In Fig. 4, the left graph of the last row illustrates that response of $\mathrm{CO}_{2}$ emission to $\mathrm{EC}$ is positive for both upper positive part and lower negative part of the graph. It implies that with the increase in $\mathrm{EC}, \mathrm{CO}_{2}$ emission may increase. Similarly, with the decrease in $\mathrm{EC}, \mathrm{CO}_{2}$ emission can also decrease.

\section{Response of Carbon dioxide Emission $\left(\mathrm{CO}_{2}\right)$ to GDP}

From the right graph of the last row in Fig. 4, it is obvious that response of $\mathrm{CO}_{2}$ emission to GDP is positive for both upper positive part and lower negative part of the graph. It implies that with the increase in GDP, $\mathrm{CO}_{2}$ emission may increase. Similarly, with the decrease in GDP, $\mathrm{CO}_{2}$ emission can also decrease.

\section{Short-run Causality between Electricity Consumption (EC), Economic Growth (GDP) and Carbon dioxide Emission $\left(\mathrm{CO}_{2}\right)$}

The corresponding results of pair-wise Granger causality test are shown in Table 5 with the direction of causality. The result of the Granger causality principally depicts three important direction of causality from the analysis: (i) The effect of electricity consumption (EC) on GDP is statistically significant at 5 percent level; (ii) The effect of electricity consumption (EC) on carbon dioxide emissions $\left(\mathrm{CO}_{2}\right)$ is statistically significant at 1 percent level; (iii) The effect of GDP on carbon dioxide emissions $\left(\mathrm{CO}_{2}\right)$ is statistically significant at 10 percent level.

Thus, electricity consumption (EC) affects GDP and carbon dioxide emissions $\left(\mathrm{CO}_{2}\right)$ but not the reverse and GDP affects carbon dioxide emissions $\left(\mathrm{CO}_{2}\right)$ but not the reverse. Therefore, the estimation exhibits unidirectional causality from electricity consumption (EC) to GDP. Ahmad and Islam (2011) conducted a research on Bangladesh and also found short-run unidirectional causality running from per capita electricity consumption to per capita GDP without any reverse causation. Moreover, Akinlo (2009) conducted a study in Nigeria and found that unidirectional causality is running from electricity consumption to real GDP. The estimation also exhibits unidirectional causality from electricity consumption (EC) to carbon dioxide emissions $\left(\mathrm{CO}_{2}\right)$. Shahbaz et al. (2014) also found that electricity consumption causes carbon dioxide emissions.

Besides, the estimation exhibits unidirectional causality from GDP to carbon dioxide emissions $\left(\mathrm{CO}_{2}\right)$ without having any reverse causation. The view of Alam (2014) in this regard is the same that $\mathrm{CO}_{2}$ emissions increase when contribution of industry and service to GDP is expansively rising.

\section{CONCLUSION}

Based on the empirical analysis and findings, it may be concluded that higher electricity consumption in Bangladesh over time may give rise to higher economic growth and more emission of carbon dioxide. Therefore, importance should be imposed on electricity generation and adoption of carbon dioxide emission reducing technology for electricity generation. However, there may raise a question that 
whether electricity consumption is only influential factor that can accelerate the economic growth; the probable answer is simply no. Because, electricity consumption is one of the key influencing factors of economic growth not all. Moreover, government should encourage local and foreign investors by ensuring friendly business environment along with generation of more electricity. Thus, government may undertake policy actions to increase electricity generation as well as attract local and overseas investors to invest more to setup industries. Only when it will be possible, then more electricity will lead to more economic growth otherwise it would be costly. Since the researcher has mentioned earlier, the findings of the study focuses on increase in generation and consumption of electricity as a prerequisite of achieving higher economic growth through facilitating rapid industrialization for Bangladesh, the top priority should be given not only on electricity generation but also on the issues of appropriate electricity distribution and management system in both short run and long run.

\section{REFERENCES}

Abdin, M.J. 2012. Preparing a Launching Pad for Industrialization, The Financial Express, 20 December, pp. 10.

Ahmad, E. and Jamil, F. 2010. The Relationship between Electricity Consumption, Electricity Prices and GDP in Pakistan, Energy Policy, 38: 6016-6025.

Akinlo, A.E. 2009. Electricity Consumption and Economic Growth in Nigeria: Evidence from Co-integration and Co-feature Analysis, Journal of Policy Modeling, 31: 681-693.

Alam, J. 2014. On the Relationship between Economic Growth and $\mathrm{CO}_{2}$ Emissions: The Bangladesh Experience, IOSR Journal of Economics and Finance, 5(6): 36-41.

Alam, K. and Sarker, A.R. 2010. Nexus between Electricity Generation and Economic Growth in Bangladesh, Asian Social Science, 6(12): 16-22.

Asaduzzaman, M. and Billah, A.H.M. 2006. Emerging Issues in Bangladesh Economy: A Review of Bangladesh's Development 2005-06, Centre for Policy Dialogue, Chapter 14, pp. 361-392.

Bhattacharya, D. 2002. Bangladesh Economy in FY2001: Macroeconomic Performance, Bangladesh Facing the Challenges of Globalisation: A Review of Bangladesh's Development 2001, University Press Limited, Dhaka, pp. 1-30.

BPDB. 2011. Annual Report 2010-2011, Bangladesh Power Development Board, Government of Peoples' Republic of Bangladesh, Bangladesh.

Buysse, J., Begum, I.A., Alam, M.J. and Huylenbroeck, G.V. 2012. Energy Consumption, Carbon Emissions and
Economic Growth Nexus in Bangladesh: Co-integration and Dynamic Causality Analysis, Energy Policy, 45: 217-225.

Cheng, B.S. 1999. Causality between Energy Consumption and Economic Growth in India: An Application of Co-integration and Error-Correction Modeling, Indian Economic Review, 34: 39-49.

Dickey, D.A. and Fuller, W.A. 1981. Likelihood ratio statistics for autoregressive time series with a unit root, Econometrica: Journal of the Econometric Society, 49(4): 1057-1072.

Enders, W. 1995. Applied econometric time series, $1^{\text {st }}$ edition, John Wiley \& Sons, New York.

Engle, R.F. and Granger, C.W.J. 1987. Co-integration and Error Correction: Representation, Estimation, and Testing, Econometrica, 55(2): 251-276.

Ferguson, R., Wilkinson, W. and Hill, R. 2000. Electricity Use and Economic Development, Energy Policy, 28: 923-934.

Ghosh, S. 2002. Electricity Consumption and Economic Growth in India, Energy Policy, 30: 125-129.

Glasure, Y.U. 2002. Energy and National Income in Korea: Further Evidence on the Role of Omitted Variables, Energy Economics, 24: 355-365.

Glasure, Y.U. and Lee, A.R. 1998. Co-integration, Error Correction and the Relationship between GDP and Energy: The Case of South Korea and Singapore, Resource and Energy Economics, 20(1): 17-25.

Imran, K. 2010. Energy Consumption and Economic Growth: A Case Study of Three SAARC Countries, European Journal of Social Sciences, 16(2): 206-224.

Lean, H.H. and Shahbaz, M. 2012. The Dynamics of Electricity Consumption and Economic Growth: A Revisit Study of their Causality in Pakistan, Energy, 39(1): 146-153.

Lutkepohl, H. 2008. Impulse Response Function, $2^{\text {nd }}$ edition, The New Palgrave Dictionary of Economics.

MacKinnon, J.G. 1996. Numerical Distribution Functions for Unit Root and Co-integration tests, Journal of Applied Economics, 11: 601-618.

Mahmud, W. 1997. 'Macroeconomic Update', in Center for Policy Dialogue, Growth or Stagnation? A review of Bangladesh's Development 1996, University Press Limited, Dhaka.

Morimoto, R. and Hope, C. 2004. The Impact of Electricity Supply on Economic Growth in Sri Lanka, Energy Economics, 26: 77-85.

Mozumder, P. and Marathe, A. 2007. Causality Relationship between Electricity Consumption and GDP in Bangladesh, Energy Policy, 35: 395-402.

Narayan, P.K. and Singh, B. 2007. The Electricity Consumption and GDP Nexus for the Fiji Islands, Energy Economics, 29: 1141-1150.

Narayan, P.K. and Smyth, R. 2009. Multivariate Granger Causality between Electricity Consumption, Export and GDP: Evidence from A Panel of Middle Eastern Countries, Energy Policy, 37: 229-36. 
Phillips, P.C.B. and Perron, P. 1988. Testing for a Unit Root in Time Series Regression, Biometrika, 75(2): 335-346.

Saeki, C. and Hossain, M.S. 2011. Does Electricity Consumption Panel Granger Cause Economic Growth in South Asia? Evidence from Bangladesh, India, Iran, Nepal, Pakistan and Sri-Lanka, European Journal of Social Sciences, 25(3): 316-328.

Shahbaz, M., Uddin, G.S., Rehman, I.U. and Imran, K. 2014. Industrialization, Electricity Consumption and $\mathrm{CO}_{2}$ Emissions in Bangaldesh, Renewable and Sustainable Energy Reviews, 31: 575-586.

Squalli, J. 2007. Electricity Consumption and Economic Growth: Bounds and Causality Analyses of OPEC Countries, Energy Economics, 29: 1192-1205.
Stern, D.I. 1993. Energy Growth in the USA: A Multivariate Approach, Energy Economics, 15: 137-150.

WB 2016. World Bank Database 2016, World Bank (WB), Washington, D.C., USA.

WDI 2016. World Development Indicators Database 2016, World Development Indicators (WDI), World Bank Publications, Washington, D.C., USA.

Yang, H.Y. 2000. A Note on the Causal Relationship between Energy and GDP in Taiwan, Energy Economics, 22(3): 309-317.

Yu, E.S.H. and Choi, J.Y. 1985. The Causal Relationship between Energy and GNP: An International Comparison, Journal of Energy and Development, 10(2): 249-272. 